\title{
Uji Aktivitas Antibakteri Ekstrak Etanol Daun Waru Gunung (Hibiscus macrophyllus) dan Fraksinya terhadap Staphylococcus aureus
}

\section{(Antibacterial Activity Test of Ethanolic Extract from Hibiscus macrophyllus Leaves and Its Fractions against Staphylococcus aureus)}

\author{
Afif Rifqie Maulana, Bawon Triatmoko*, Moch. Amrun Hidayat \\ Fakultas Farmasi Universitas Jember \\ Jln. Kalimantan 37, Jember 68121 \\ e-mail korespondensi: bawon.farmasi@unej.ac.id
}

\begin{abstract}
Infection is one of the main causes of world health problems, especially in developing countries like Indonesia, one of which is an acute respiratory infection caused by bacteria such as Staphylococcus aureus. Therapeutics are used for the treatment of infections today with antibiotics. However, there are many cases of bacterial resistance to antibiotics that need to develop alternatives derived from plants. One of the plants that have antibacterial activity is the leaves of Waru Gunung (Hibiscus macrophyllus). The purpose of this study was to determine whether the ethanolic extract of $H$. macrophyllus leaves and their fractions have antibacterial activity against $S$. aureus. The method used in this antibacterial activity test is the disk diffusion method with a test concentration of $5 \%$, $10 \%, 15 \%, 20 \%$, and $25 \%$. The results of this study indicate that all test samples have antibacterial activity except in the water fraction. The highest antibacterial activity was obtained in the ethyl acetate fraction which attracted semipolar compounds in the ethanolic extract of $H$. macrophyllus leaves. The antibacterial activity of the test samples in sequence from high to low includes ethyl acetate fraction, ethanolic extract, $n$-hexane fraction, and water fraction.
\end{abstract}

Keywords: infection, antibacterial, disc diffusion, H. macrophyllus leaves.

\begin{abstract}
Abstrak
Infeksi merupakan salah satu penyebab utama masalah kesehatan dunia terutama di negara berkembang seperti Indonesia, salah satunya adalah infeksi saluran pernapasan akut (ISPA) yang disebabkan oleh bakteri seperti Staphylococcus aureus. Terapi yang digunakan untuk pengobatan infeksi saat ini dengan pemberian antibiotik. Namun demikian banyak kasus resistensi bakteri terhadap antibiotik sehingga perlu dikembangkannya alternatif yang bersumber dari tumbuhan. Salah satu tumbuhan yang memiliki aktivitas antibakteri adalah daun Waru Gunung (Hibiscus macrophyllus). Tujuan dari penelitian ini adalah untuk mengetahui apakah ekstrak etanol daun $H$. macrophyllus dan fraksinya memiliki aktivitas antibakteri terhadap $S$. aureus. Metode yang digunakan pada uji aktivitas antibakteri ini adalah metode difusi cakram dengan konsentrasi uji $5 \%$, $10 \%, 15 \%$, 20\%, dan 25\%. Hasil penelitian ini menunjukkan bahwa semua sampel uji memiliki aktivitas antibakteri kecuali pada fraksi air. Aktivitas antibakteri tertinggi didapat pada fraksi etil asetat yang menarik senyawa semipolar pada ekstrak etanol daun $H$. macrophyllus. Aktivitas antibakteri sampel uji secara berurutan dari tinggi ke rendah antara lain fraksi etil asetat, ekstrak etanol, fraksi n-heksana, dan fraksi air.
\end{abstract}

Kata kunci: infeksi, antibakteri, difusi cakram, daun waru gunung. 


\section{Pendahuluan}

Infeksi merupakan salah satu penyebab utama masalah kesehatan dunia terutama di negara berkembang seperti Indonesia [1]. Infeksi merupakan satu dari sepuluh besar penyakit yang terjadi di Indonesia, diantaranya adalah infeksi saluran pernapasan dengan prevalensi sebesar 5,2\% [2]. Contoh dari infeksi saluran pernapasan adalah ISPA (infeksi saluran pernapasan akut) yang menyerang saluran pernapasan mulai dari hidung sampai alveoli. Infeksi ini dapat disebabkan oleh bakteri seperti Staphylococcus aureus [3]. Hasil Riset kesehatan dasar 2018 melaporkan ISPA menyumbang prevalensi sebesar $4,4 \%$ dengan jumlah 168.406 kasus di Indonesia [4].

Terapi yang digunakan untuk pengobatan infeksi saat ini yaitu dengan pemberian antibiotik. Namun banyak kasus resistensi bakteri terhadap antibiotik diakibatkan penggunaan antibiotik yang tidak rasional [5]. Resistensi bakteri terhadap antibiotik menjadi perhatian dunia saat ini sehingga perlu dikembangkannya alternatif pengganti antibiotik yang bersumber dari tumbuhan. Pengobatan yang berasal dari tumbuhan memiliki beberapa keuntungan seperti pengobatan yang murah namun efek samping yang lebih kecil dan mudah diterima pasien [6].

Senyawa aktif pada tumbuhan memiliki aktivitas antibakteri yang telah dibuktikan oleh beberapa penelitian sebelumnya. Salah satu tumbuhan yang memiliki senyawa aktif yang dapat menghambat bakteri adalah tumbuhan genus Hibiscus. Ekstrak etanol daun $H$. macrophyllus dilaporkan memiliki aktivitas antibakteri terhadap pertumbuhan Bacillus cereus [7]. Namun belum diketahui golongan senyawa berdasarkan kepolarannya yang berpotensi sebagai antibakteri dari ekstrak etanol daun $H$. macrophyllus tersebut. Pada penelitian ini dilakukan uji aktivitas antibakteri ekstrak etanol daun waru gunung $(H$. macrophyllus) dan fraksinya terhadap $S$. aureus.

\section{Metode Penelitian Alat dan Bahan}

Alat yang digunakan pada penelitian ini adalah spatula logam, alat-alat gelas, alat penggiling, neraca analitik (Sartonius CP224S), ultrasonikator, vortex (Labnet), corong buchner, oven (Memmert), jarum ose, pembakar spiritus, yellow tip, blue tip, cawan petri, mikropipet (SOCOREX ASBA S.A), inkubator (Gallenkamp), autoklaf (ALP), hot plate, rotary evaporator (Heidolph), corong pisah, laminar air flow (Airtech), jangka sorong, alumunium foil, kertas saring, microtip, microtube, plat tetes, plastic wrap.

Bahan yang digunakan untuk ekstraksi dan fraksinasi antara simplisia daun $H$. Macrophyllus, etanol 96\%, n-heksana p.a, etil asetat p.a. Bahan yang digunakan untuk uji antibakteri antara lain DMSO (Dimetil Sulfoksida) $10 \%$, aquades steril, standar Mc Farland 0.5, dan $\mathrm{NaCl}$ fisiologis. Bakteri uji yang digunakan adalah $S$. aureus. Media yang digunakan untuk peremajaan bakteri metode difusi adalah Agar Mueller Hinton (MHA). Kontrol positif yang digunakan untuk uji aktivitas antibakteri adalah gentamisin cakram $10 \mu \mathrm{g}$.

\section{Prosedur Penelitian}

Sampel yang digunakan adalah daun yang diambil secara acak dari tumbuhan waru gunung H. macrophyllus. Daun H. macrophyllus tumbuh di kebun warga Desa Glantangan Kecamatan Tempurejo Kabupaten Jember. Selanjutnya dideterminasi di Laboratorium Tanaman Politeknik Negeri Jember.

Sampel daun waru gunung yang diperoleh disortasi basah, kemudian dicuci untuk menghilangkan kotoran. Daun waru gunung dikeringkan selama 14 hari tanpa sinar matahari langsung dan diangin-anginkan hingga menjadi kering ditandai dengan hancur saat diremas. Setelah daun waru gunung kering, daun waru gunung dilakukan proses grinding dengan alat penggiling dan serbuk dimasukkan kedalam plastik kering untuk dilakukan proses ekstraksi.

Proses ekstraksi diawali dengan menimbang 250 gram serbuk daun $H$. macrophyllus dilarutkan menggunakan pelarut etanol 96\% sebanyak 2 liter (perbandingan 1:8), kemudian proses ekstraksi menggunakan metode ultrasonikasi selama 1 jam. Kemudian disaring menggunakan kertas saring melalui corong Buchner dan didapatkan filtrat. Filtrat dipekatkan menggunakan vaccum rotary evaporator pada suhu $50^{\circ} \mathrm{C}$ kemudian dikeringkan dalam oven hingga diperoleh ekstrak kental. Perhitungan rendemen ekstrak menggunakan persamaan rumus:

$$
\frac{\text { berat ekstrak kental }(g)}{\text { berat serbuk }(g)} \times 100 \%
$$

Setelah diperoleh ekstrak kental, ekstrak difraksinasi dengan cara pastisi cair-cair dengan pelarut n-heksana, etil asetat, dan etanol $96 \%$-air (perbandingan 1:9). Sebanyak 10 gram ekstrak dilarutkan dalam $10 \mathrm{ml}$ etanol $96 \%$, setelah larut 
kemudian ditambahkan aquades sebanyak $90 \mathrm{ml}$. Larutan tersebut dipartisi dengan menambahkan $100 \mathrm{ml}$ n-heksana p.a (perbandingan 1:1), dikocok dalam corong pisah kurang lebih 15 menit dan didiamkan hingga terbentuk dua lapisan (pada lapisan atas n-heksana dan pada lapisan bawah etanol 96\%-air). Lapisan nheksana diambil dan dilakukan tiga kali penambahan n-heksana hingga menjadi bening, lapisan etanol 96\%-air kemudian difraksinasi kembali menggunakan pelarut etil asetat p.a dengan cara yang sama dan didapatkan air. Hasil fraksinasi dari n-heksana, etil asetat, dan air ditampung selama beberapa waktu kemudian dipekatkan dalam lemari asam dan oven hingga diperoleh fraksi kental untuk digunakan sebagai sampel pengujian antibakteri (Sembiring dkk., 2016). Perhitungan rendemen fraksi menggunakan rumus:

$$
\frac{\text { berat fraksi }(g)}{\text { berat ekstrak }(g)} \times 100 \%
$$

Sterilisasi alat dan bahan dilakukan dengan pemijaran dan uap. Sterilisasi pemijaran dilakukan dengan cara pembakaran alat-alat diatas lampu spiritus seperti jarum ose, spreader kaca dan pinset. Sterilisasi uap dilakukan dengan autoklaf suhu $121^{\circ} \mathrm{C}$ selama 15 menit untuk alatalat gelas, yellow tip, blue tip, aquades steril, media Nutrient Agar (NA), media Mueller Hinton (MHA), dan $\mathrm{NaCl}$ fisiologis.

Pembuatan media NA dilakukan dengan menimbang serbuk NA sebanyak 0,69 gram dilarutkan dalam $30 \mathrm{ml}$ aquades lalu dipanaskan sampai mendidih dan tepat larut. Larutan media dituangkan ke dalam 6 tabung reaksi dengan volume masing-masing $5 \mathrm{~mL}$. Media NA disterilkan menggunakan autoklaf suhu $121^{\circ} \mathrm{C}$ selama 15 menit. Kemudian Media NA steril dimiringkan hingga terbentuk agar miring.

Pembuatan media MHA dilakukan dengan menimbang serbuk MHA sebanyak 13,68 gram dilarutkan dalam $360 \mathrm{~mL}$ aquades dan dipanaskan sampai mendidih hingga semuanya larut. Larutan media dituangkan ke dalam 24 tabung reaksi dengan volume $15 \mathrm{~mL}$. Media kemudian disterilkan dengan autoklaf pada suhu $121^{\circ} \mathrm{C}$ selama 15 menit.

Biakan bakteri murni diremajakan pada media Nutrient Agar (NA) dalam tabung reaksi dengan cara menggoreskan pada media NA miring. Proses tersebut dilakukan secara aseptis yaitu dengan mendekatkan mulut tabung reaksi pada nyala api dalam Laminar Air Flow (LAF).
Setelah itu, media dalam tabung reaksi yang berisi bakteri ditutup rapat dengan menggunakan kapas dan plastic wrap kemudian diinkubasi selama 18 jam dalam inkubator pada suhu $37^{\circ} \mathrm{C}$.

Bakteri S. aureus dari kultur biakan murni diambil menggunakan jarum ose steril, kemudian dimasukkan ke dalam tabung reaksi yang berisi $10 \mathrm{~mL} \mathrm{NaCl}$ fisiologis secara aseptis lalu divortex hingga larut. Kekeruhan suspensi bakteri diperiksa menggunakan spektrofotometer UV-Vis pada panjang gelombang $625 \mathrm{~nm}$ dengan absorbansi 0,08-0,13 [11].

Uji aktivitas antibakteri metode difusi cakram dilakukan menggunakan lima konsentrasi ekstrak etanol daun waru gunung dan lima konsentrasi larutan uji fraksi yaitu $5 \%$, $10 \%, 15 \%, 20 \%$, dan 25\%. Diawali dengan membuat larutan induk $25 \%$ kemudian di encerkan dengan DMSO $10 \%$ menjadi konsentrasi $5 \%, 10 \%, 15 \%$, dan $20 \%$. Kontrol positif menggunakan cakram gentamisin $10 \mu \mathrm{g}$ dan kontrol negatif menggunakan DMSO 10\%.

Uji antibakteri ekstrak dan fraksi dengan metode difusi cakram dilakukan masing-masing dua kelompok yaitu kelompok perlakuan dan kelompok kontrol. Kelompok perlakuan berisi lima cakram yang sudah didiamkan dengan larutan uji ekstrak dan larutan uji fraksi sebanyak $15 \mu \mathrm{L}$ pada plat tetes dengan konsentrasi masing-masing $5 \%, 10 \%, 15 \%, 20 \%$, dan $25 \%$. Kelompok kontrol berisi cakram yang didiamkan dalam DMSO 10\% steril (kontrol negatif) dan cakram gentamisin $10 \mu \mathrm{\mu g}$ (kontrol positif). Selanjutnya larutan media MHA dimasukkan kedalam empat cawan petri steril, 1 cawan petri untuk uji antibakteri dengan larutan uji ekstrak dan tiga cawan petri untuk larutan uji fraksi. Suspensi bakteri dalam $\mathrm{NaCl}$ fisiologis 0,9\% dipipet sebanyak $100 \mu \mathrm{L}$ dan dimasukkan kedalam masing-masing cawan petri, kemudian suspensi diratakan dengan spreader kaca. Kemudian letakkan cakram yang berisi larutan uji dan dua cakram kontrol kedalam masing- masing cawan petri. Selanjutnya masing-masing cawan petri yang berisi cakram perlakuan dan cakram kontrol diinkubasi selama 18 jam dalam inkubator pada suhu $37^{\circ} \mathrm{C}$. Kemudian zona bening yang terbentuk sekitar cakram diukur diameternya dengan jangka sorong.

Data yang diperoleh berupa data kuantitatif dilakukan uji normalitas dan uji homogenitas. Kemudian dilakukan uji One way ANOVA jika diperoleh data normal dan homogen. Selanjutnya dilakukan analisis statistika dengan LSD post hoc. Hasil uji dianggap berbeda signifikan apabila nilai $p<0,05$ dengan tingkat 
kepercayaan 95\% [4].

\section{Hasil Penelitian}

Hasil pengujian aktivitas antibakteri ekstrak etanol daun waru gunung dan fraksinya terhadap Staphylococcus aureus menggunakan konsentrasi $5 \%, 10 \%, 15 \%, 20 \%$, dan $25 \%$ dengan kontrol positif cakram gentamisin $10 \mu \mathrm{g}$ dan kontrol negatif DMSO 10\% ditunjukkan pada Gambar 1 - 4

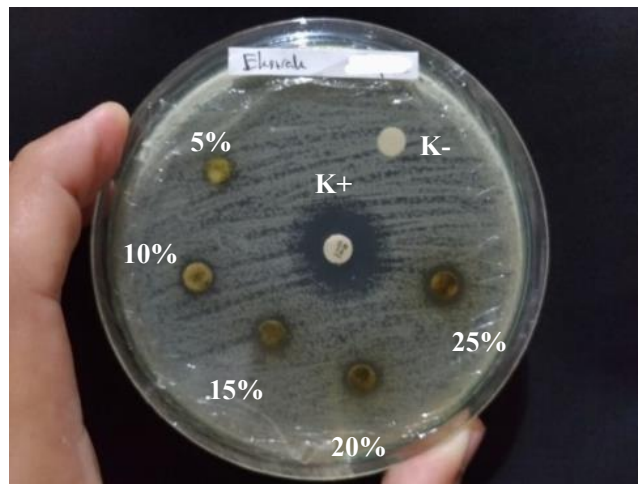

Gambar 1. Hasil Uji Aktivitas antibakteri metode difusi cakram ekstrak etanol $96 \%$ daun waru gunung ( $H$. macrophyllus) terhadap S. aureus konsentrasi 5\%, $10 \%, 15 \%, 20 \%, 25 \%$, kontrol positif gentamisin $10 \mu \mathrm{g}$, dan kontrol negatif DMSO $10 \%$.

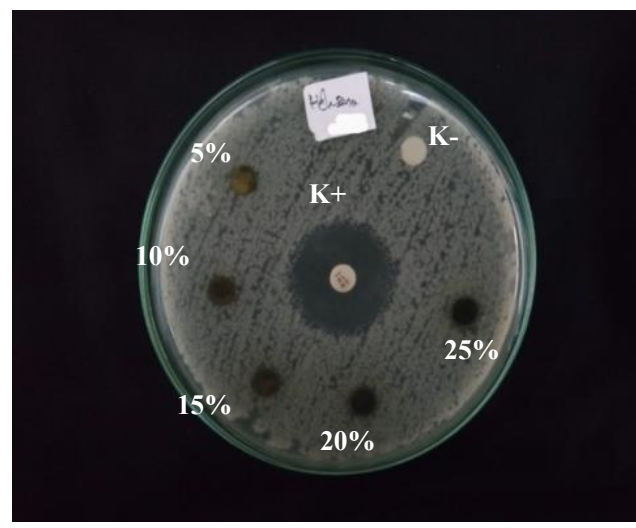

Gambar 2. Hasil Uji Aktivitas antibakteri metode difusi cakram fraksi n-heksana dari ekstrak etanol daun waru gunung $(H$. macrophyllus) terhadap S. aureus konsentrasi $5 \%, 10 \%, 15 \%, 20 \%$, $25 \%$, kontrol positif gentamisin 10 $\mu \mathrm{g}$, dan kontrol negatif DMSO 10\%.

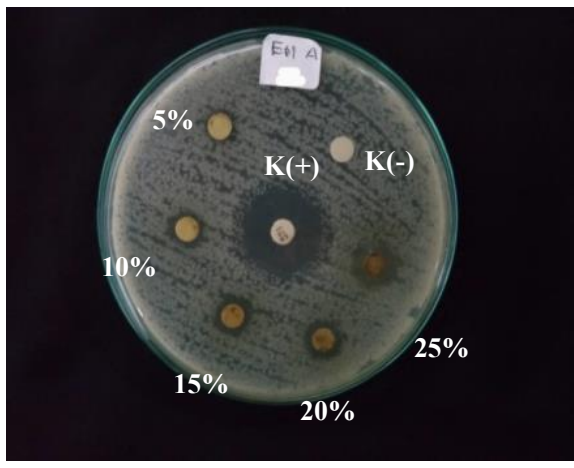

Gambar 3. Hasil Uji Aktivitas antibakteri metode difusi cakram fraksi etil asetat dari ekstrak etanol daun waru gunung $(H$. macrophyllus) terhadap S. aureus konsentrasi $5 \%, 10 \%, 15 \%, 20 \%$, $25 \%$, kontrol positif gentamisin 10 $\mu \mathrm{g}$, dan kontrol negatif DMSO 10\%

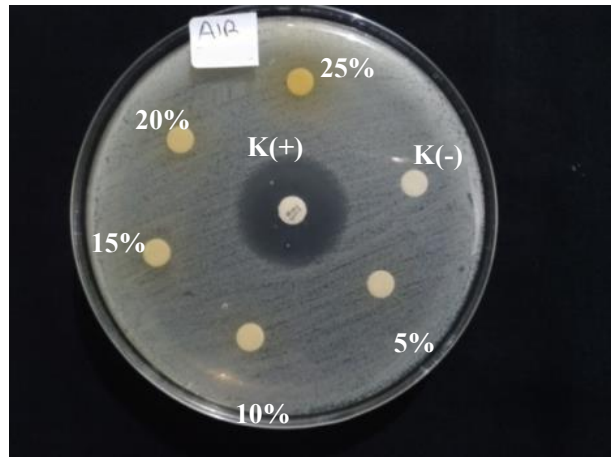

Gambar 4. Hasil Uji Aktivitas antibakteri metode difusi cakram fraksi air dari ekstrak etanol daun waru gunung $(H$. macrophyllus) terhadap S. aureus konsentrasi $5 \%, 10 \%, 15 \%, 20 \%$, $25 \%$, kontrol positif gentamisin 10 $\mu \mathrm{g}$, dan kontrol negatif DMSO 10\%

Ekstrak etanol 96\%, fraksi n-heksana dan fraksi etil asetat daun waru gunung $(H$. macrophyllus) memiliki aktivitas antibakteri terhadap Staphylococcus aureus pada konsentrasi $5 \%, 10 \%, 15 \%, 20 \%$, dan $25 \%$ yang diketahui dengan terbentuknya zona bening atau zona hambat disekitar cakram sampel uji. Pada fraksi air tidak terbentuk adanya zona hambat sehingga kemungkinan kandungan senyawa yang tertarik pada fraksi air bukan senyawa yang berpotensi sebagai antibakteri atau membutuhkan konsentrasi yang lebih tinggi agar terbentuk zona hambat pada bakteri. Zona hambat yang terbentuk diukur diameternya dengan menggunakan jangka sorong dari tiga 
arah yang berbeda dan ketika dibuat garis bertemu pada satu titik tengah. Data hasil pengukuran dilakukan uji analisis statistika.

Tabel 1. Hasil pengukuran diameter zona hambat dan perbedaan signifikansi antar konsentrasi dan antar sampel

\begin{tabular}{|c|c|c|}
\hline Sampel & $\begin{array}{c}\text { Konsentrasi } \\
\text { Uji }\end{array}$ & $\begin{array}{c}\text { Diameter Hambat } \\
(\mathrm{mm})\end{array}$ \\
\hline Ekstrak & $5 \%$ & $8,25 \pm 0,14(a, 1)$ \\
\hline Etanol & $10 \%$ & $8,97 \pm 0,17(b, 1)$ \\
\hline \multirow[t]{5}{*}{$96 \%$} & $15 \%$ & $9,60 \pm 0,31(c, 1)$ \\
\hline & $20 \%$ & $10,04 \pm 0,14^{(d, 1)}$ \\
\hline & $25 \%$ & $11,58 \pm 0,10(e, 1)$ \\
\hline & Kontrol (+) & $18,09 \pm 0,16^{(f, 1)}$ \\
\hline & Kontrol (-) & 0 \\
\hline \multirow{7}{*}{$\begin{array}{l}\text { Fraksi n- } \\
\text { Heksana }\end{array}$} & $5 \%$ & $7,59 \pm 0,18^{(a, 1)}$ \\
\hline & $10 \%$ & $8,24 \pm 0,44(a, b, 1)$ \\
\hline & $15 \%$ & $9,18 \pm 0,89(b, c, 1)$ \\
\hline & $20 \%$ & $9,64 \pm 0,55(\mathrm{c}, \mathrm{d}, 1)$ \\
\hline & $25 \%$ & $10,31 \pm 0,67^{(\mathrm{d}, 1)}$ \\
\hline & Kontrol (+) & $19,07 \pm 0,74(\mathrm{e}, 2)$ \\
\hline & Kontrol (-) & 0 \\
\hline \multirow{7}{*}{$\begin{array}{c}\text { Fraksi Etil } \\
\text { Asetat }\end{array}$} & $5 \%$ & $8,28 \pm 0,33^{(a, 2)}$ \\
\hline & $10 \%$ & $9,47 \pm 0,37(b, 2)$ \\
\hline & $15 \%$ & $10,40 \pm 0,50(b, c, 1)$ \\
\hline & $20 \%$ & $10,71 \pm 0,58^{(c, 1)}$ \\
\hline & $25 \%$ & $12,04 \pm 0,70(\mathrm{~d}, 2)$ \\
\hline & Kontrol (+) & $19,51 \pm 0,48(e, 3)$ \\
\hline & Kontrol (-) & 0 \\
\hline \multirow[t]{7}{*}{ Fraksi Air } & $5 \%$ & 0 \\
\hline & $10 \%$ & 0 \\
\hline & $15 \%$ & 0 \\
\hline & $20 \%$ & 0 \\
\hline & $25 \%$ & 0 \\
\hline & Kontrol (+) & $21,14 \pm 0,03^{(a, 4)}$ \\
\hline & Kontrol (-) & 0 \\
\hline
\end{tabular}

Keterangan :

1) Notasi huruf yang berbeda menunjukkan hasil antar konsentrasi yang berbeda signifikan dalam satu sampel

2) Notasi huruf yang sama menunjukkan hasil antar konsentrasi yang tidak berbeda signifikan dalam satu sampel

3) Notasi huruf ganda menunjukkan konsentrasi tersebut tidak berbeda signifikan pada huruf yang sama dalam satu sampel

4) Notasi angka yang bebeda menunjukkan hasil antar sampel yang berbeda signifikan dalam satu konsentrasi

5) Notasi angka yang sama menunjukkan hasil antar sampel yang tidak berbeda signifikan dalam satu konsentrasi

6) Data disajikan dalam rata-rata $\pm \mathrm{SD}(\mathrm{mm})$

7) Replikasi dilakukan sebanyak 3 kali

\section{Pembahasan}

Pada hasil analisis menunjukkan bahwa nilai $p>0,05$ yang artinya esktrak etanol dan fraksinya terdistribusi normal dan homogen. Kemudian dilanjutkan analisis uji post hoc untuk mengetahui daya hambat antar konsentrasi dan antar sampel berbeda signifikan atau tidak dengan uji LSD (Least Significantly Difference) [8]. Pada tabel 1 hasil analisis uji LSD antar konsentrasi menunjukkan adanya perbedaan signifikan pada sampel ekstrak dan beberapa tidak berbeda signifikan pada sampel fraksi kecuali fraksi air tidak dapat dianalisis. Hal ini menunjukkan semakin tinggi konsentrasi sampel uji yang diberikan maka semakin tinggi pula zona hambat bakteri yang dihasilkan. Hasil analisis uji LSD antar sampel menunjukkan beberapa perbedaan signifikan pada konsentrasi $5 \%, 10 \%$, dan $25 \%$ namun tidak adanya perbedaan yang signifikan pada konsentrasi $15 \%$ dan $20 \%$. Hal ini menunjukkan bahwa pada konsentrasi $15 \%$ dan $20 \%$ semua sampel uji kecuali fraksi air memberikan zona hambat bakteri yang tidak jauh berbeda. Pada sampel ekstrak etanol dan fraksi etil asetat hasil analisis menunjukan tidak adanya perbedaan signifikan pada semua konsentrasinya, hal ini menunjukan bahwa fraksi etil asetat memberikan zona hambat yang tidak jauh berbeda dengan ekstrak etanol. Kontrol positif pada sampel esktrak etanol dan fraksinya menunjukkan perbedaan yang signifikan.

Seluruh sampel uji memberikan zona diameter hambat $\leq 14 \mathrm{~mm}$ pada konsentrasi $5 \%$, $10 \%, 15 \%, 20 \%$, dan $25 \%$ hal ini menunjukkan bahwa pada konsentrasi tersebut ekstrak etanol dan fraksinya memberikan respon hambat yang lemah terhadap pertumbuhan $S$. aureus. Kontrol positif memberikan zona hambat diameter sekitar 18-21 mm menunjukkan bahwa cakram gentamisin memberikan respon hambat pertumbuhan bakteri sedang hingga kuat terhadap $S$. aureus [9]. Kontrol negatif tidak memberikan zona hambat pada hasil penelitian. Hal ini menunjukkan bahwa DMSO 10\% yang digunakan sebagai kontrol negatif merupakan kosolven yang baik yang dapat melarutkan sampel uji tanpa memberikan pengaruh penghambatan terhadap pertumbuhan bakteri.

Aktivitas antibakteri dari yang tinggi ke rendah secara berurutan adalah fraksi etil asetat dan ekstrak etanol, fraksi n-heksana, dan fraksi air. Fraksi etil asetat mempunyai aktivitas paling tinggi terhadap pertumbuhan $S$. aureus namun tidak berbeda signifikan dengan ekstrak etanol. Dugaan senyawa semipolar yang tertarik pada fraksi etil asetat adalah senyawa flavonoid dan alkaloid [10] yang memiliki aktivitas antibakteri. Flavonoid membentuk senyawa kompleks dengan protein ekstraseluler dan alkaloid 
mencegah terbentuknya lapisan dinding sel dengan cara mengganggu komponen penyusun peptidoglikan sehingga lapisan dinding sel tidak terbentuk dan menyebabkan kerusakan pada sel bakteri [11].

\section{Simpulan dan Saran}

Berdasarkan hasil penelitian yang dilakukan, Ekstrak etanol daun waru gunung $(H$. Macrophyllus) dan fraksinya memiliki aktivitas antibakteri, kecuali fraksi air tidak memiliki aktivitas antibakteri pada konsentrasi $5 \%, 10 \%$, $15 \%, 20 \%$, dan $25 \%$. Pada penelitian ini semua sampel uji kecuali fraksi air memberikan daya hambat bakteri yang berbeda signifikan pada konsentrasi $5 \%$, $10 \%$, dan $25 \%$ namun pada konsentrasi $15 \%$ dan $20 \%$ tidak adanya perbedaan yang signifikan. Pada sampel esktrak dan fraksi etil asetat menunjukkan tidak adanya perbedaan yang signifikan pada semua konsentrasinya.

Saran untuk penelitian selanjutnya adalah perlu penelitian lebih lanjut terkait skrining fitokimia pada fraksi n-heksana, fraksi etil asetat, dan fraksi air dari ekstrak etanol $96 \%$ daun waru gunung $(H$. macrophyllus) untuk memastikan metabolit sekunder yang terkandung tiap fraksi; perlu dilakukan isolasi senyawa terhadap fraksi daun waru gunung ( $H$. macrophyllus) untuk memastikan kandungan senyawa kimia spesifik yang paling berpotensi sebagai sebagai antibakteri; dan perlu dilakukan penelitian lebih lanjut aktivitas antibakteri daun waru gunung $(H$. macrophyllus) terhadap bakteri gram positif dan gram negatif lain.

\section{Daftar Pustaka}

[1] Departemen kesehatan. 2008. Riset Kesehatan Dasar (RISKESDAS) 2007. Jakarta: Departemen kesehatan RI.

[2] WHO. 2015. WHO satistical profil indonesia. Indonesia: WHO Statistical Profil. 1-3.
[3] WHO. 2007. Epidemic prone and pandemic prone acute respiratory diseases: infection prevention and control in helath-care facilities. Who. Indonesia Partner in Development. 53(2):8-25.

[4] Kemenkes RI. 2018. Hasil Utama Riskesdas 2018. Jakarta: Kemenkes RI

[5] Kuswandi M. 2011. Strategi Mengatasi Bakteri yang Resisten terhadap Antibiotika. Pengukuhan Jabatan Guru Besar (10-12). Yogyakarta: Fakultas Farmasi Universitas Gadjah Mada.

[6] Tavish MH, DH. dan Martosupono M. 2002. An economic study of essential oil production in the uk: a case study comparing non-uk lavender/lavandin production and peppermint/spearmint production with uk production techniques and cost. Adas Consulting Ltd. 137

[7] Agustina RP. 2017. Skrining Fitokimia Dan Uji Aktivitas Antibakteri Ekstrak Etanol Daun Waru Gunung (H. macrophyllus Roxb. Ex Hornem) Terhadap Bacillus cereus. Skripsi. Jember: Fakultas Farmasi Universitas Jember.

[8] Sudjana. 2000. Metode Statistika. Tarsito, Bandung

[9] CLSI. 2012. Methods for Dilution Antimicrobial Susceptibility Test for Bacteria That Grow Aerobically; Approved StandardNinth Edition. Wayne. 2. Clinical and Laboratory Standards Institute.Robinson, T., 1995, Kandungan Organik Tumbuhan Tinggi, Edisi VI, Hal 191-216, Diterjemahkan oleh Kosasih Padmawinata, ITB, Bandung.

[10] Sarker SD, Latif Z, dan Gray Al. 2006. Natural Product Isolation Second Edition. New Jersey, USA: Human Press.

[11] Robinson T, 1995, Kandungan Organik Tumbuhan Tinggi, Edisi VI, Hal 191-216, Diterjemahkan oleh Kosasih Padmawinata, ITB, Bandung. 